\begin{tabular}{lcr}
\hline \multicolumn{1}{c}{ A N N A L E S } \\
UNIVERSITATIS & MARIAE CURIE-SKŁODOWSKA \\
LUBLIN - POLONIA & \\
VOL. XXII, 2 & SECTIOK & 2015 \\
\hline
\end{tabular}

Instytut Politologii Uniwersytetu Zielonogórskiego

WIOLETTA HUSAR

\title{
Komodyfikacja Fútbol Club Barcelona i wykorzystanie elementów katalońskości jako wartości dodanej brandingu
}

Comodification of Fútbol Club Barcelona and the use of the Catalan elements as a value-added branding

\author{
ABSTRACT
}

Powszechna komercjalizacja niemal wszystkich aspektów życia jednostki jest determinantą zmian we współczesnym świecie. Komodyfikacja, branding poszerzają swoje strefy wpływów w zawrotnym tempie. W związku z tym nie mogły ominąc także sfery sportu i etniczności. Kreowanie marki FC Barcelony ma charakter specyficzny, gdyż jest kompilacją tego co globalne z tym co lokalne. Katalońskość stanowi niejako wartość dodaną klubu, silną podbudowę, która jednocześnie pozwala odróżnić markę premium Barçy od pozostałych. Jednocześnie towar, który jest wyjątkowy, z łatwością odnajduje się na rynku ekonomicznym i generuje pożądane zyski.

Słowa kluczowe: FC Barcelona, katalońskość, komodyfikacja, branding, futbol

\section{WSTĘP}

Obecnie niemal każdy obszar życia i relacje społeczne są podporządkowane zasadom rynku. Procesy supermarketyzacji i komercjalizacji obejmują coraz to nowe płaszczyzny przez zaadaptowanie wzorców zachowań charakterystycznych dla relacji handlowych (komercyjnych) i przeniesienie ich na grunt pozaekonomiczny [Szlendak 2004: 58-100]. Priorytetem stają się kryteria rynkowe (ekonomiczne), a tym samym rentowne są tylko te dobra i działalność ludzka, które pomnażają zyski wytwórcy, co ściśle koresponduje z zapotrzebowaniem społeczeństwa. Nie powinna dziwić zatem potrzeba poszukiwań nisz rynkowych czy nieeksploatowanych dotychczas towarów. Redefinicja klasycznego pojmowania towaru sprawia, iż komodyfikacja może 
dotyczyć praktycznie wszystkich zagadnień. Ściśle koreluje to z pogłębiającym się trendem kreowania i wykorzystania marki, a często kompilacji marek. Przykładem tego typu procesów jest budowa marki premium (globalnej) przez FC Barcelonę na podbudowie marki (etnomarki) katalońskiej (regionalnej).

Głównym celem niniejszego artykułu jest analiza komodyfikacji (utowarowienia) hiszpańskiego klubu piłkarskiego Fútbol Club Barcelona ${ }^{1}$ i wykorzystanie przez niego elementów katalońskości. Wspomniana katalońskość stanowi w tym wypadku wartość dodaną zespołu, a tym samym kreowanej przez niego marki globalnej. Jego osiągnięciu ma służyć zbadanie samego sportu w kontekście towaru, a następnie komodyfikacji oraz związanego z nią brandingu klubów futbolowych na przykładzie Dumy Katalonii. Następnie weryfikacji poddano to, w jaki sposób Barça adaptuje markę katalońską - etnomarkę dla podbudowy własnej marki globalnej. Analizę skonstruowano na podstawie badań zawartych w literaturze przedmiotu, opracowaniach, materiałach prasowych i filmowych oraz źródłach internetowych.

\section{WSZYSTKO NA SPRZEDAŻ. SPORT JAKO TOWAR}

Chłonność rynku w decydującej mierze jest zdeterminowana przez dominację światopoglądu konsumpcyjnego, który traktuje jako wartości ostateczne te, które są uchwytne praktycznie [Zeidler-Janiszewska 1998: 118]. Tym samym konsumeryzm postrzegany jako hedonistyczny materializm stanowi nadrzędną cechę współczesnego społeczeństwa, społeczeństwa konsumpcyjnego².

1 W niniejszym artykule nazwa ta będzie stosowana zamiennie ze skrótem FC Barcelona oraz określeniami: Barça (skrót nazwy klubu w języku katalońskim), Blaugrana (nazwa katalońska od bordowo-granatowych barw klubu), Azulgrana (nazwa kastylijska od bordowo-granatowych barw klubu) oraz Duma Katalonii (przydomek nadany przez samych Katalończyków).

2 Społeczeństwo konsumpcyjne odznacza się konsumpcjonistycznym stylem życia, czyli masową konsumpcją, do czego przyczyniła się tzw. era fordyzmu (Henry Ford skonstruował "masowego” konsumenta), zob.: G. Adamczyk, Moralność w warunkach społeczeństwa konsumpcyjnego, „Zeszyty Naukowe KUL” 2012, 55, nr 1 (217). Zygmunt Bauman określił je mianem społeczeństw konsumentów, „które promuje wybór konsumpcyjnego stylu życia i strategii życiowych, zachęca do niego lub przymusza, pogrążając w niełasce wszelkie jego kulturowe alternatywy. Przystosowanie się do zaleceń kultury konsumpcyjnej i ścisłe ich przestrzeganie jest praktycznie w tym społeczeństwie jedynym aprobowanym bez zastrzeżeń wyborem, wyborem możliwym w praktyce do przyjęcia i przeprowadzenia. Jest on implikowany warunkiem przyznania społecznego członkostwa, zob.: Z. Bauman, Konsumowanie życia, Wydawnictwo Uniwersytetu Jagiellońskiego, Kraków 2009; szerzej zob.: J. Szacki, Historia myśli socjologicznej, PWN, Warszawa 2002; A. Aldridge, Konsumpcja, Wydawnictwo Sic, Warszawa 2006; M. Miczyńska-Kowalska, Spoleczeństwo konsumenckie jako rys kultury ponowoczesnej w ujęciu Zygmunta Baumana, [w:] Kultura a rynek, S. Patrycki (red.), Wydawnictwo KUL, Lublin 2008; G. Ritzer, Magiczny świat konsumpcji, Wydawnictwo Literackie MUZA S.A., Warszawa 2001; Z. Bauman, Praca, konsumpcjonizm i nowi ubodzy, Wydawnictwo WAM, Kraków 2006; F. Bylok, Kultura i konsumpcja we wspótczesnym społeczeństwie, [w:] Kultura a rynek, S. Patrycki (red.), Wydawnictwo KUL, Lublin 2008. 
Proces komercjalizacji nie ominął współczesnego sportu, jako składową kultury konsumpcyjnej, która zyskała miano towaru. Postrzegając sport - towar jako efekt pracy ludzkiej, który przeznaczony jest do sprzedaży i odzwierciedla społeczny stosunek relacji na linii sprzedający-kupujący, podkreśla się jednocześnie wartość użytkową owego elementu. Całokształt posiadanych przez niego właściwości sprawia, iż jest w stanie zaspokoić dane potrzeby, stając się tym samym przedmiotem społecznego zapotrzebowania [Księżyk 2002: 290-291]. W przypadku sportu zachodzi zatem proces kreacji ze społecznych podmiotów w przedmioty (towary).

Urynkowienie sportu obligatoryjnie jest związane z utowarowieniem rywalizacji sportowej. Współczesna hiperkonkurencja i gospodarka rynkowa są determinantami intensywnych poszukiwań coraz to bardziej niestandardowych towarów. Takim założeniom hołduje utowarowienie (komodyfikacja), które ma na celu transformację towarów, usług, koncepcji, idei itp. z posiadanych przez nie wartości użytkowych na wartości wymienne [Kopytoff 2003: 249-274]. Silna rywalizacja rynkowa wymusza poszukiwanie obszarów niszowych, co pozwala na objęcie dominacji na danym rynku. W konsekwencji mamy do czynienia z komodyfikacją samego sportu, jak również jego poszczególnych elementów: klubów sportowych, sportowców oraz kibiców. Wartością dodaną do towaru jest treść kulturowa, która również podlega regułom popytu - podaży i w tym właśnie kontekście stanowi clou niniejszych rozważań. Do atrybutów tego pokroju należy zaliczyć: historię klubu, tradycję, kulturę, logo i barwy klubowe, hymn, organizacje kibiców, miejsce rozgrywek, sylwetki sportowców i pracowników oraz osadzenie wszystkich tych elementów po „wewnętrznej stronie stadionów”.

Jak zaznaczyli Dominik Antonowicz, Radosław Kossowski i Tomasz Szlendak [2011: 113-139], ważnym aspektem utowarowienia sportu jest ,przetworzenie” kibiców w Mckibiców. Jest to jednoznaczne z tym, iż „,kibice - niekonsumenci stają się rodzajem »odpadu«, industrialnym przeżytkiem w postindustrialnym świecie kultury konsumpcyjnej. Są niewygodnym balastem, utrudniającym transformację rozgrywek piłkarskich w komercyjną działalność, ponieważ wyznawane przez nich wartości, przywiązanie do tradycji oraz normy zachowań są fundamentalnie antykomercyjne" [Antonowicz, Szlendak, Kossowski 2012: 5]. Swoista komercjalizacja kibiców implikuje segmentacją społeczeństwa na biednych i bogatych, ich komodyfikacją oraz rodzi proces makdonaldyzacji.

Kultura konsumpcji stawia w centrum konsumpcjonizm, który ma stać się antidotum na wszystkie problemy nowoczesnego człowieka. De facto założenie to może potwierdzać nakreślona przez Goffreya Millera zależność: „marketing jest kluczowy dla nowoczesnej kultury, a konsumpcyjnie sprofilowany umysł dla marketingu" [Miller 2009: 52]. W związku z powyższym kultura, kluby sportowe, organizacje sportowe (np. FIFA, UEFA) czy nawet w tym konkretnym przypadku protonarody, jak np. Katalończycy, są zobligowane do przekształcenia się w dynamicznie prosperujące korporacje. 
Poruszając kwestie komodyfikacji i katalońskości $i^{3}$ postrzeganej przez pryzmat etniczności ${ }^{4}$ oraz określenia ich wzajemnych relacji, należy podkreślić w tym kontekście istotę procesu budowania własnej marki ${ }^{5}$, towar bowiem, który staje się gwarancją określonej jakości oraz zyskuje kluczowe znaczenie na rynku, stymuluje powstawanie rozpoznawalnej marki o rozmaitej podbudowie. W analizowanym przypadku dochodzi do połączenia i zazębienia się obu towarów: klubu sportowego i katalońskości.

\section{FC BARCELONA JAKO EGZEMPLIFIKACJA „FUTBOLOWEGO TOWARU”}

Nierozerwalnie z komercjalizacją i supermarketyzacją sportu wiąże się utowarowienie klubów sportowych. W niniejszym opracowaniu szczególną uwagę poświecono Fútbol Club Barcelona, który w swojej strategii marketingowej połączył lokalność z globalnością oraz katalońskość z kosmopolityzmem, co prócz wzmocnienia marki klubu przyczyniło się również do ugruntowania marki katalońskiej. Komercjalizacja klubu sportowego niesie ze sobą nie tylko konsekwencje w postaci zmian reguł rywalizacji sportowej na bardziej medialne. Pokłosiem są zmiany w funkcjonowaniu społeczności regionalnej, która traktuje Barçę jako fundamentalny element budowy tożsamości katalońskiej.

Wyraźnie widać, iż obecny świat futbolu przeżywa okres niesamowitego przyspieszenia, w którym prym wiedzie niekoniecznie uzyskanie jak najlepszego wyniku sportowego (aczkolwiek ma on nadal duże znaczenie w kontekście generowania zysków), co zysk finansowy czerpany z całej sfery biznesu sportowego. D. Antonowicz, R. Kossowski i T. Szlendak dowiedli, że komercjalizacja piłki nożnej opiera się na zasadach turbokapitalizmu. Trudno zaprzeczyć temu przekonaniu, zważywszy na fakt, iż konsekwencją tej formy kapitalizmu jest wyraźny bipolarny

3 Rozumiany jako zespół elementów budujących i podtrzymujących tożsamość Katalończyków oraz poczucie ich odmienności wobec pozostałych mieszkańców wspólnot autonomicznych Hiszpanii. Składa się na niego m.in. kultura, tradycja, historia czy prowadzona polityka. To wzajemne poczucie wspólnoty katalońskiej, relacje między jednostkami, które uważają się za Katalończyków. Często określają się także mianem narodu.

${ }_{4}$ Autorka przyjmuje za T.H. Eriksenem, iż etniczność jest ,aspektem relacji społecznych między osobami, które uważają siebie za zasadniczo odmienne od członków innych grup, których istnienia są świadome i z którymi utrzymują stosunki. Można ją zatem też zdefiniować jako tożsamość społeczną (opartą na kontraście względem innych), nacechowaną metaforycznym lub fikcyjnym poczuciem pokrewieństwa", zob.: T.H. Eriksen, Etniczność i nacjonalizm. Ujęcie antropologiczne, thum. B. Gutowska-Nowak, Wydawnictwo Uniwersytetu Jagiellońskiego, Kraków 2013.

5 Jest to identyfikacja produktu z jego producentem i przenoszenie swoistych dla wytwórcy cech na produkt i odwrotnie.

6 Współczesna forma kapitalizmu z turbodoładowaniem, w którym najważniejsza jest efektywność rynkowa pozbawiona jakiejkolwiek kontroli i respektowania zasad społecznych i gospodarczych. Priorytetem jest zysk ekonomiczny, zob.: L. Edward, Turbokapitalizm. Zwycięzcy i przegrani światowej gospodarki, tłum. E. Kania, Wydawnictwo Dolnośląskie, Wrocław 2000. 
podział świata na bogatych i biednych. Analogicznie, turbokapitalizm prowadzi do rozwarstwienia wśród klubów futbolowych, w których linią demarkacyjną są zyski oraz wygenerowany rozłam na ultrabogaczy i niezamożnych. W ten sposób rodzi się kolejny podział piłkarskiego świata o dwóch astronomicznie różnych prędkościach: globalnym i lokalnym [Antonowicz, Szlendak Kossowski 2012: 5].

Stosując klucz i terminologię, jaką zaproponował Immanuel Wallerstein [2007], można dokonać dychotomicznego podziału na centrum i peryferie oraz wyodrębnić pośredni stopien - półperyferie - w odniesieniu do klubów futbolowych na podstawie takich kryteriów, jak np.: wskaźniki ekonomiczne, uzyskiwane wyniki, zaawansowanie w klubowym brandingu ${ }^{7}$ itp.

W centrum znajdują się kluby „hegemoniczne”, potentaci skomercjalizowanego biznesu futbolowego, którzy osiągają największe zyski, osiągają sukcesy sportowe (m.in. zwycięstwa w Lidze Mistrzów), zgromadzili licznych sponsorów, najlepszych zawodników, są potęgą medialną, a w rzeczywistości najczęściej pochodzą z matecznika ,wielkiej piątki”. Ponadto zbudowana przez nich marka ma charakter globalny.

W hierarchii na niższym stopniu zaawansowania i sprostania wymogom rynku ekonomicznego znajdują się półperyferyjne kluby, które aspirują do grona mocarstw piłkarskich, są one jednak wewnętrznie zróżnicowane pod wieloma względami. Formalnie mają możliwość awansu, jednak w rzeczywistości jest to mało prawdopodobne, gdyż na wstępie przegrywają w starciach z futbolowymi gigantami. Pomimo to sporadycznie udaje się im na krótką chwilę wejść w orbitę klubów centralnych. Najczęściej gracze peryferyjni znajdują się na etapie budowy marki narodowej. Pozostała część świata klubowego mieści się na peryferiach wielkiego biznesu piłki nożnej [Antonowicz, Szlendak Kossowski 2012: 19-21]. Nie są one w stanie podjąć walki z najlepszymi i przegrywają na każdej płaszczyźnie: finansowej, medialnej, sportowej, społecznej itd. Marka klubów peryferyjnych nie jest atrakcyjna dla szerszego grona odbiorców, prezentuje raczej poziom lokalny, regionalny. Nie jest bowiem nowością, iż wartość klubów i piłkarzy szacuje się w kategoriach ekonomicznych.

Klub FC Barcelona jest podmiotem specyficznym, gdyż pomimo iż był w zasadzie klubem regionalnym, dzięki ewolucji, racjonalnemu zarządzaniu i najnowocześniejszym narzędziom marketingowym stał się jedną z najbardziej rozwiniętych marek futbolowych na świecie. Chcąc wydostać się z zapaści finansowych i utrzymać w centrum, zmuszono go do częściowego zreformowania polityki klubowej. Obecnie dysponuje jednym z najpotężniejszych budżetów klubowych na świecie. Budżet Barçy z roku na rok jest zwiększany, dla przykładu na sezon 2014/2105 wynosił $530 \mathrm{mln}$ euro, co stanowi 10 razy więcej niż budżet sprzed 10 lat. Marketing bazujący na rozpoznawalności klubu przyciąga niczym magnez potężne firmy, m.in.: Audi, Nike, Qatar Airways [Campo Vidal, Mestres 2015]. Solidną podbudowę stanowią bowej.

Czyli kształtowanie marki klubu i jego sprzedaż jako towaru w obudowie w postaci kultury kluAnglia, Niemcy, Francja, Hiszpania, Włochy. 
liczne inicjatywy pozasportowe organizowane na stadionie, które dodatkowo generują pokaźne profity, np. koncerty, targi, wystawy, imprezy okolicznościowe itd.

Dzięki programom marketingowym i edukacji dewiza: „Més que un club” jest rozpoznawana na całym globie. Sprzyja temu działalność Fundació FC Barcelona, która za swoją misję uznaje ,promowanie charakterystycznego modelu społecznego poprzez rozwój solidarności, działalność kulturalną i edukacyjną (zarówno na własną rękę, jak i w ramach współpracy) w celu konsolidacji społecznego zaangażowania Barça jako »Więcej niż klub« w Katalonii i na świecie, nadając mu wyjątkowy wymiar w skali globalnej"". Klub przekazuje $0,7 \%$ zysków na wspomnianą fundację. Dodatkowo jej fundusz wspierają indywidualnie piłkarze. Działalność organizacji jest kierowana przede wszystkim do dzieci. Urzeczywistnienie wspomnianego hasła odbywa się m.in. przez działalność społeczną. Duma Katalonii współpracuje m.in. z ONZ i jej agendami UNICEF, UNESCO i UNHCR/ACNUR.

Budowa silnej pozycji klubu była możliwa również dzięki arcyważnemu miejscu futbolu w Hiszpanii i na świecie. W monarchii bardzo intensywnie rozwinęły się media sportowe - w samej Barcelonie mieszczą się dwa dzienniki sportowe. Dodatkowo każdego wieczoru hiszpańskie radio nadaje 1,5-godzinny program sportowy. Popularne wśród widzów są sportowe talk show, retransmisje wszystkich spotkań i programy na żywo z analizami eksperckimi. Kibice mogą niemal uczestniczyć w życiu klubu. Trend ten jest wzmacniany dodatkowo budowaniem dobrych relacji z mediami społecznościowymi. Mają one charakter dwutorowy, tzn. klub zarządza własnymi mediami i stroną internetową, jednocześnie dba o aktywność piłkarzy w Internecie [Campo Vidal, Mestres 2015] (zwłaszcza na Twitterze, Facebooku czy Instagramie).

Strategia marketingowa Blaugrany w mediach społecznościowych zasadza się na trzech podstawowych krokach: dotarciu do jak najszerszej grupy odbiorców (odbiorca globalny), stworzenie treści, które zwiążą ich z klubem, zaś ostatnim etapem jest czerpanie wymiernych zysków. Obecnie najlepsze możliwości dotarcia do blisko $300 \mathrm{mln}$ kibiców zespołu i poszerzenie tego grona o nowych fanów stwarza Internet, zwłaszcza media społecznościowe.

Intensyfikacja przekazu medialnego wizerunku drużyny przynosi zwielokrotnienie zysków, np. przychody z praw telewizyjnych za grę w Primera División w sezonie 2013/2014. Barça i Real Madryt otrzymały $150 \mathrm{mln}$ euro, zaś trzecia w kolejności Valencia zaledwie $48 \mathrm{ml}$ euro [Campo Vidal, Mestres 2015]. Tak duża rozbieżność wynika $\mathrm{z}$ faktu, iż kluby indywidualnie negocjują stawki z nadawcami telewizyjnymi, co tylko potwierdza status marki globalnej FC Barcelony.

$\mathrm{Na}$ wartość komercyjną klubu składa się także utowarowienie samych piłkarzy. Od pewnego czasu futbol jest oferowany w pakiecie, np. z muzyką, modą, sztuką itd. Dzieje się to za sprawą np. relacji piłkarzy z gwiazdami sceny muzycznej, czego przykładem na gruncie barcelońskim jest związek Shakiry i Gerarda Piqué lub

9 Fundació FC Barcelona, http://fundacio.fcbarcelona.cat/ Oficjalna strona internetowa Fundacji FC Barcelona (dostęp: 27.11.2015). 
udział sportowców w przedsięwzięciach charytatywnych czy angażu w reklamach. FC Barcelona dba oto, aby jej piłkarze byli prezentowani jako „gladiatorzy” naszych czasów, ucieleśnienie cnót, świecący przykładem mężczyźni, perfekcyjnie realizujący swoje role społeczne jako mężowie, ojcowie czy przyjaciele. Duże zdyscyplinowanie w tej kwestii nie omija również żon i partnerek piłkarzy [Campo Vidal, Mestres 2015]. Klub stara się w ten sposób „ocieplać” swój wizerunek i pielęgnuje relacje z mediami oraz sponsorami. Nie oznacza to jednak, że w zupełności unika skandali - pojawiające się sporadycznie, zwiększają medialność i zainteresowanie widza/czytelnika/słuchacza.

Kibice FC Barcelony również nie uniknęli procesu komercjalizacji. Pokazuje to już specyficzna struktura własności: wszyscy kibice, którzy zapiszą się do klubu, stają się w równym stopniu jego współwłaścicielami. Członków klubu jest ponad 150 tys. Powstaje w ten sposób struktura więzi nie tylko finansowych, ale przede wszystkim emocjonalnych. Kibice są niejako współodpowiedzialni za losy i kondycję klubu, chętnie angażują się w jego życie społeczne. Piramida wieku członków jest niemal odbiciem społeczeństwa miasta, co wskazuje na przekazywanie z pokolenia na pokolenie tradycji kibicowania i zamiłowania do klubu, a członkiem pozostaje się najczęściej aż do śmierci (długoterminowi klienci). Pomimo że stadion liczy 100 tys. miejsc, kupno biletów dla „zwykłego kibica” jest bardzo trudne, gdyż blisko 85 tys. z nich trafia do członków (jako „stałego klienta”), zatem ich wartość rzeczywista jest zwielokrotniona ${ }^{10}$, tym samym jednostki zasiadające na trybunach tworzą swoisty kibicowski establishment.

Dzięki intensywnej promocji klubu przez tournée po niemal całym świecie, akcje reklamujące, mecze towarzyskie, inicjatywy charytatywne, poszerzanie swoich wpływów na nowych chłonnych rynkach, gdzie futbol jeszcze jest słabo rozwinięty, jak np. Chiny czy Indie, stale wzrasta liczba kibiców, co gwarantuje wzrost dochodów ze sprzedaży gadżetów, biletów, prasy czy większą oglądalność transmisji meczy. Na całym świecie funkcjonuje blisko 1400 klubów kibica Barçy, z czego ponad 100 jest poza Hiszpanią. Zrzeszają one ponad 150 tys. zarejestrowanych kibiców. Pomimo że dzieli ich duży dystans geograficzny, łączy więź emocjonalna. Warto podkreślić, iż bez znaczenia są tu przekonania polityczne czy religijne oraz kolor skóry, co stanowi rzadkość w środowiskach kibicowskich.

\section{KATALOŃSKOŚĆ - WARTOŚĆ DODANA KLUBU}

Marka zyskuje coraz większe znaczenie w przypadku państw, gdyż o jego „miękkiej sile" decydują m.in. takie elementy, jak postrzeganie międzynarodowe i wizerunek państwa. Widoczne są także dążenia do pomiaru marki państwa, np. Nation Brand

${ }_{10}$ Zwłaszcza że do wolnej sprzedaży trafia niewiele biletów, gdyż pozostałe 15 tys. jest rozdysponowywane kibicom drużyny przeciwnej i rozmaitym instytucjom. 
Index (NBI) Simona Anholta [Ociepka 2012: 134]. Katalonia nie jest samodzielnym organizmem państwowym, ale jak pokazuje obecna intensyfikacja ruchu secesjonistycznego, przejawia takie aspiracje. Na potrzeby niniejszego artykułu, traktując Katalonię jako twór na wzór quasi-państwa, nietrudno zauważyć, jak misternie buduje swoją markę, postrzeganą jako (pozytywne) wartości kojarzone z danym państwem i społeczeństwem, co implikuje (pozytywny) stosunek wobec państwa. Swoisty branding narodowy, zdaniem Daryla Copelanda, „obejmuje opowiadanie unikatowej historii i jej wyrażenie jako zintegrowanej narracji o klarownym kształcie i celu" [Copeland 2011: 186]. Innymi słowy jest to specyficzny sposób opowiadania światu o swoim narodzie i państwie [Schneider 2004: 1], eksport swojej historii, kultury, tradycji, a z czasem polityki. Ewolucja pojęcia budowy marki wskazuje, iż branding państw i branding narodów staje się nieodzownym elementem polityki i komunikacji państwa/narodu. Jak podkreśla Nadia Kaneva, biorąc pod uwagę funkcję, jaką pełni marka, ,zrekonstruowanie narodowości na poziomie zarówno ideologii, jak i praktyki, dzięki temu rozumienie i doświadczana realność przynależności narodowej i kształtowania tego co narodowe (national governance) zmieniają się w sposób dotąd nieznany" [Kaneva 2011: 4], czego doskonałym przykładem są Katalończycy.

Katalońskość w rozumieniu „zasobów miękkich” quasi-państwa i jako „towar deficytowy", odznaczający się wysoką jakością i specyficznością, stanowi nie tylko towar, ale oryginalną markę samą w sobie. Przenosząc powyższy proces na grunt kataloński, można zaryzykować stwierdzenie, iż tożsamość etniczna (narodowa), będąca etnomarką, jest budowana dla sprzedaży katalońskich zasobów kulturowych, etnicznych i narodowych. Zatem pierwotnie musiało dojść do uprzedmiotowienia, utowarowienia wskazanych zasobów. Można więc założyć, iż zbiorowość etniczna, jaką tworzą Katalończycy, przekształciła się w podmiot na wzór przedsiębiorstw komercyjnych, oferując bogaty zasób „własnych towarów” [Comaroff, Comaroff 2011: 30], będąc jednocześnie producentem i dystrybutorem kulturowo-etniczno-narodowego asortymentu. Uzyskujemy w ten sposób wcieloną tożsamość, która rozciąga się na nowe grupy i w wyniku ,inkorporacji” wykracza poza tradycyjną wspólnotę, tym samym poszerza rynki zbytu.

W dużej mierze Barça budowę swojej marki oparła o tzw. non-product-sttributes, a więc konfigurację historii, tradycji klubu, logo, barw klubowych, atmosfery na stadionie, więzi z kibicami. Wszystko to można sprowadzić do tożsamości klubu, a w przypadku Blaugrany jest to jednocześnie tożsamość katalońska. Silna podbudowa tożsamościowa dała doskonałą podwalinę pod budowę marki globalnej, ponieważ to owa wartość dodana jest determinantą stopnia identyfikacji z klubem. Niemniej jednak to decydujący element w przypadku kibiców - konsumentów „lojalnych na dobre i złe", nie zaś dla Mckibiców, dla których oferta musi zawierać: najlepsze wyniki, zapewniać rozrywkę, nadawać poczucie elitarności (podniesienie swojego statusu w oczach innych), zaś tożsamość klubowa może stać się atrakcyjna wówczas, gdy jest odpowiednio „obrandowana”. W związku z tym Barça, aby utrzymać się w gronie potęg futbolowych, musiała ewoluować z marki regionalnej w markę globalną, która 
a natura rei jest najbardziej dochodową. Niemniej jednak bycie marką globalną nie dyskwalifikuje możności pozostawania jednocześnie marką regionalną. Tak też jest w przypadku Blaugrany, która stała się światową ambasadorką Katalonii.

Historia Barçy nieustannie przeplata się z historią regionu, kształtowaniem się tożsamości narodowej i nacjonalizmu katalońskiego ${ }^{11}$. Już założyciel klubu - Hans Gamper - popierał ideę katalońskości, wspierał dążenia Katalończyków do uzyskania autonomii, ponadto posługiwał się językiem katalońskim. Duma Katalonii jako swoisty amalgamat znaczeń zespolił emblematy klubowe z symboliką katalońską. Herb drużyny (L'escut) zawiera krzyż św. Jerzego, patrona Katalonii oraz la senyere ${ }^{12}$, która stała się fundamentalnym atrybutem opraw rozgrywek piłkarskich. Ponadto zawiera także bordowo-granatowe barwy klubowe oraz w centralnym jego miejscu znajduje się napis „FCB”. Sama nazwa ma również wyraz symboliczny, ponieważ podczas reżimu gen. Francisca Franco zmieniono nazwę na hiszpańsko brzmiącą Club de Futbol Barcelona ${ }^{13}$. W przeciwieństwie do wielu klubów hiszpańskich, FC Barcelona nigdy nie wcieliła do swojej symboliki elementów symptomatycznych dla monarchii hiszpańskiej. Za to do differentia specifica klubu należy postać Czarnej Madonny z klasztoru w Montserrat ${ }^{14}$.

Barwy klubowe są uzupełniane przez barwy narodowe i odwrotnie. Flaga katalońska ma symbolicznie wzmacniać doping dla Barçy. Kolorystykę katalońską tworzą sami kibice: układają misterną mozaikę z blisko 60 tysięcy żółtych i czerwonych arkuszy papieru. Powstaje ona przed rozpoczęciem meczu i jak zauważa Magdalena Czech, „,stanowi ważny element emocjonalny i estetyczny oprawy piłkarskich spotkań" [Czech 2011: 245].

El Segadors - hymn regionu wybrzmiewa podczas najważniejszych meczów na Camp Nou. Hymn drużyny Cant del Barça ${ }^{15}$, w swoich słowach wysławia wspólnotę (Katalonię) i sport (futbol) jako wartości nadrzędne. Retoryka ta oscyluje wokół założeń umiarkowanego nacjonalizmu [Myśliwiec 2006: 189]. Jego główny zwolennik Jordi Pujol stworzył definicję Katalończyka na podstawie znajomości języka katalońskiego: „Ten, kto używa języka katalońskiego i mówi po katalońsku do swoich dzieci, jest prawdziwym Katalończykiem" [Pujol 1976, cyt. za: Strubell 1988: 151]. Katalończycy przywiązują ogromną rolę do swojego języka i uważają go za jeden z filarów swojej tożsamości. Ma to zapewne związek z tym, iż wielokrotnie rząd centralny starał się wyrugować język kataloński z przestrzeni publicznej. Władze

11 Zob.: Ł. Wojcieszak, D. Głuszek-Szafraniec, Ewolucja ustroju polityczno-terytorialnego Hiszpanii (1975-2010). Przykład Kraju Basków, Katalonii i Galicji, Wyższa Szkoła Administracji, Bielsko-Biała 2011, s. 167-183; A. Antczak, Kształtowanie się tożsamości narodowej wspólnot autonomicznych w Hiszpanii, AON, Warszawa 2008, s. 134-167.

12 Oficjalna flaga katalońska.

13 Dopiero w 1974 r. powrócono do pierwotnej nazwy.

14 Klasztor benedyktyński, który stał się ośrodkiem pielgrzymkowym i ostoją dla nacjonalistów katalońskich.

15 Posiadał kilka wersji. Obecnie przyjęto za hymn drużyny Cant del Barça. 
klubu aktywnie uczestniczą $\mathrm{w}$ jego resuscytacji, m.in. zapewniają zawodnikom zagranicznym naukę języka katalońskiego i kultury katalońskiej, również kontrakty podpisywane są w llengua catalana ${ }^{16}$.

Stadion Barcelony nie pełni wyłącznie funkcji „świątyni futbolu”, jest także „świątynią katalońskości”. To tu odbywają się główne obchody święta narodowego (Diada Nacional de Catalunya $)^{17}$ oraz pokazy narodowego tańca sardana. Klub zgodnie z propagowaną przez Katalończyków otwartością wobec świata chętnie zrzesza piłkarzy zagranicznych, ale zdecydowanie gloryfikuje znaczenie wychowanków z regionalnej szkółki La Masía. Ponadto należy podkreślić, iż Duma Katalonii posiada szkółki piłkarskie w różnych państwach świata, m.in. w Polsce, co zdecydowanie pomaga $\mathrm{w}$ propagowaniu klubowych idei i przekazu, a jednocześnie wspiera promocję klubu.

Futbol i sam klub stały się rodzajem spoiwa, posiadają potencjał integrujący. Jak zauważa Carles Feixa: „Barça jest doskonałym wyrazem otwartej i integracyjnej polityki Katalonii wobec imigrantów: dla większości przybyszów identyfikacja z klubem sportowym stanowi pierwszy krok do rozpoczęcia nauki języka katalońskiego i włączenia się w życie regionu" [Feixa 1992: 17]. Sami Barcelończycy powtarzają, iż każdy, kto kibicuje Dumie Katalonii, jest Katalończykiem i nie ma w tym przypadku znaczenia pochodzenie. Zaznaczone jest to w Cant del Barça: „som la gent blaugrana, Tant se val d'on venim si del sud o del nord ara estem d'acord, ara estem d'acord, una bandera ens agermana” (,Jesteśmy bordowo-granatowi, nieważne skąd jesteśmy czy to północ, czy południe ale, jesteśmy zgodni, jesteśmy zgodni, gdyż łączy nas flaga)" "18. Co należy zaznaczyć, kibice innego barcelońskiego klubu - Reial Club Deportiu Espanyol de Barcelona są uznawane za nie-Katalończyków i wręcz popleczników frankistowskiego reżimu, pomimo iż starają się przez różne zabiegi nadać mu kataloński wymiar.

Zespolenie FC Barcelony z katalońskością sprawiło, iż stała się ona metonimią narodu katalońskiego, zwłaszcza za dyktatury gen. Franco, który dążył wszelkimi sposobami do unicestwienia kultury, języka, symboliki oraz wszelkich innych przejawów odrębności katalońskiej. Stadion był jedyną możliwą areną buntu, świątynią katalońskości, miejscem rywalizacji nie tylko sportowej, lecz także politycznej.

Barceloński klub doskonale wykorzystuje wspomniane elementy katalońskości dla celów marketingowych. Jego starcia z Realem Madryt - odwiecznym wrogiem, elektryzują cały świat futbolu ${ }^{19}$. El Clàssico skupia uwagę tysięcy kibiców na sta-

${ }_{16}$ W języku katalońskim.

17 Katalonia - kultura i tradycje katalońskie, http://www.catalunya-polonia.com/page.php?id=66 (dostęp: 27.11.2015).

18 Hymn FC Barcelony, http://www.fcbarca.com/hymn.html (dostęp: 29.11.2015).

19 Zob.: T. Leplat, FC Barcelona - Real Madryt. Wojna Światów, tłum. W. Wąsowski, Amber, Warszawa 2014; A. Relaño, Barça vs. Real. Wrogowie, którzy nie moga bez siebie żyć, tłum. B. Bardadyn, Wydawnictwo SQN, Kraków 2015; F. Foer, Jak futbol wyjaśnia świat czyli nieprawdopodobna teoria globalizacji, tłum. A. Czarnecka, Lublin 2006. 
dionie i miliony przed telewizorami [Duch Salvador 2005: 134], rodząc przy tym niesamowite emocje. Mecz piłkarski jest rytuałem budowy tożsamości i jej kontestacji, swoistym futbolowym nacjonalizmem [Kulesza-Gulczyńska 2013: 184-196]. Rywalizacja ta odzwierciedla kulturowo-etniczny podział Hiszpanii. Wzajemna niechęć jest widoczna również poza murawą boiska: liczne afery, potyczki na transfery zawodników, sugestywne wypowiedzi piłkarzy, trenerów, prezesów, skandale sędziowskie itd. Jednak przede wszystkim jest to walka podsycana dla obopólnych korzyści drużyn. Gran Derbi generuje ogromne zyski dla klubów ze strony reklamodawców, zaś kibice masowo zakupują gadżety, gotowi zapłacić wygórowane sumy za bilety czy zasiadając przed telewizorami i napędzając tym samym biznes futbolowy.

Ducha wzajemnych relacji FC Barcelony i katalońskości oddaje były prezydent FC Barcelony Joan Laporta, który zauważa, że sukces drużyny to nie jest tylko sportowa wygrana: „To sprawa modelu klubu. Modelu z ideałami. Bez ideałów jesteśmy niczym. Ideałów futbolowych i narodowych. [...] Barça najbardziej katalonistyczna w swojej historii jest też najbardziej uniwersalną Barça wszechczasów i tą, która zdołała zebrać największe plony na niwie sportowej. Zwycięska Barça jest więcej niż klubem i reprezentuje pewien model myślenia i życia. Wychodzi daleko poza futbol. Uosabiamy najbardziej emocjonujący epos w historii, który prowadzi uciskane narody ku wolności" ${ }^{20}$. Za rządów Joana Laporty, promującego wizerunek zespołu jako etnomarki Katalonii, klub był bardzo silnie upolityczniony i hołdował otwarcie nacjonalizmowi katalońskiemu.

\section{ZAKOŃCZENIE}

Branding znalazł zastosowanie we wszelakich dziedzinach i stał się spoiwem na wielu płaszczyznach. Jednocześnie pozwolił wielu z nich wydobyć to, co w nich najcenniejsze, aczkolwiek w dużej mierze zapomniane lub zbagatelizowane. Niemniej jednak niesie on ze sobą zagrożenie, chociażby w postaci odarcia danych elementów, np. tradycji, kultury czy etniczności, ze sfery sacrum. Katalońskość jest specyficznym produktem i wymaga odpowiedniego traktowania, zaś zbudowana na tym fundamencie etnomarka musi łączyć w sobie sacrum i profanum.

Wykorzystanie przez skomercjalizowane kluby sportowe podwalin regionalnych na wzór tego, co uczyniła FC Barcelona, zyskuje na popularności. Niemniej jednak można sądzić, iż o tak dużym sukcesie obu marek zadecydowała specyfika zależności między nimi i stopień wzajemnego przenikania. Korzyści z tego zespolenia płyną dla obu stron: Barça wykreowała globalną markę, markę premium na bazie zakorzenienia w marce lokalnej - katalońskiej. Egzotyczny przekaz tego co regionalne, rodzime w zglobalizowanym świecie przybiera na znaczeniu. Katalońskość stała się

${ }^{20}$ FC Barcelona jako przykład symbolu tożsamości narodowej Katalończyków, http://pldocs.org/ docs/index-6386.html?page=2 (dostęp: 27.11.2015). 
wartością dodaną do marketingowego wizerunku klubu, ocieplając go i sprawiając, że stał się on bliższy odbiorcy. Nie każda marka ma taką podbudowę, co czyni z FC Barcelony towar unikatowy. Potwierdza to tylko regułę, że nie ma lokalności bez globalności i globalizmu bez lokalizmu.

Jednocześnie Katalończycy, mając takiego paradyplomatę, jak Duma Katalonii, mogą znacznie wzmocnić swoją pozycję społeczną, polityczną czy gospodarczą. Kwestia zespołu i tego, gdzie będzie grać po ogłoszeniu ewentualnej niepodległości Katalonii ${ }^{21}$, ma również swój udział w dyskursie politycznym, gdyż brak takiego hegemona w rozgrywkach hiszpańskich znacznie osłabi futbol w tym państwie, na czym straciłaby również Barça. Klub jest swoistą partią polityczną, która ucieleśnia interesy Katalończyków i podkreśla ich tożsamość. Jako czynnik scalający, element zbiorowej identyfikacji, ma możliwość globalnego oddziaływania na społeczność międzynarodową, a zatem na politykę wielu państw. W związku z tym futbol zostaje uwikłany w politykę nie tylko regionalną czy krajową, ale światową. Potwierdza to tezę, iż sport jest doskonałym nośnikiem idei narodowych ${ }^{22}$. Będzie on zatem miał także znaczenie przy dalszym rozwoju kwestii secesji Katalonii.

\section{BIBLIOGRAFIA}

Adamczyk G. 2012. Moralność w warunkach społeczeństwa konsumpcyjnego, „Zeszyty Naukowe KUL”, nr 1 (217).

Aldridge, A. 2006. Konsumpcja, Wydawnictwo Sic, Warszawa.

Antczak, A. 2008. Kształtowanie się tożsamości narodowej wspólnot autonomicznych w Hiszpanii, AON, Warszawa.

Antonowicz, D., Kossakowski, R., Szlendak, T. 2011. Ostatni bastion antykonsumeryzmu? Kibice industrialni w dobie komercjalizacji sportu, „Studia Socjologiczne”, nr 3.

Antonowicz, D., Szlendak, T., Kossakowski, R. 2012. Piłkarz jako marka i peryferyjny kibic jako Aborygen. O wybranych społecznych konsekwencjach komercjalizacji sportu, „Kultura i Społeczeństwo”, nr 3.

Bauman, Z. 2006. Praca, konsumpcjonizm i nowi ubodzy, Wydawnictwo WAM, Kraków.

Bauman, Z. 2009. Konsumowanie życia, Wydawnictwo Uniwersytetu Jagiellońskiego, Kraków.

Branding Post-Communist Nations. Marketizing National Identities in the New Europe, 2011, N. Kaneva (ed.), Routledge, London.

Bylok, F. 2008. Kultura i konsumpcja we współczesnym społeczeństwie, [w:] Kultura a rynek, S. Patrycki (red.), Wydawnictwo Katolickiego Uniwersytetu Lubelskiego, Lublin.

Campo Vidal, L., Mestres, C. 2015. FCB - Pasion y Negocio, Sagesse SL, film wyemitowany przez Canal+ HD.

21 Zob. szerzej o kwestii niepodległości Katalonii, np.: Úrsula de Serrallonga, El déficit fiscal de Cataluña con España, Òmnium Cultural, Barcelona 2000; A. López Tena, Cataluña bajo España. La opresión national en democracia, Dèria Editors, SL, Barcelona 2009; D. Conversi, The Basques, the Catalans and Spain. Alternative Routes to Nationalist Mobilisation, Hurst \& Company, Londyn 1997.

22 Zob. J. Hargreaves, Freedom For Catalonia? Catalan Nationalism, Spanish Identity and the Barcelona Olympic Games, Cambrige University Press, Cambrige 2000. 
Comaroff, J., Comaroff, J.L. 2011. Etniczność sp. z o.o., Wydawnictwo Uniwersytetu Jagiellońskiego, Kraków.

Conversi, D. 1997. The Basques, the Catalans and Spain. Alternative Routes to Nationalist Mobilisation, Hurst \& Company, London.

Copeland, D. 2011. The Seven Paradoxes of Public Diplomacy, [w:] Trials of Engagement. The Future of US Public Diplomacy, A. Fischer, S. Lucas (eds.), Martinus Nijhoff Publishers, Leiden.

Czech, M. 2011. Jak pojemne jest Camp Nou? Mit FC Barcelona i jego funkcje, [w:] Spoteczne zmagania ze sportem, Ł. Rogowski, R. Skrobacki (red.), Wydawnictwo Uniwersytetu im. Adama Mickiewicza, Poznań.

Duch Salvador, J. 2005. Futbol, metáfora d'una guerra Freda, Barcelona.

Edward, L. 2000. Turbokapitalizm. Zwycięzcy i przegrani światowej gospodarki, thum. E. Kania, Wydawnictwo Dolnośląskie, Wrocław.

Eriksen, T.H. 2013. Etniczność i nacjonalizm. Ujęcie antropologiczne, tłum. Barbara Gutowska-Nowak, Wydawnictwo Uniwersytetu Jagiellońskiego, Kraków.

FC Barcelona jako przykład symbolu tożsamości narodowej Katalończyków, http://pldocs.org/docs/index-6386.html?page=2 (dostęp: 27.11.2015).

Feixa, C. 1992. El Barça un fenomen inexplicable?, Segre-lectura 14 VI.

Foer, F. 2006. Jak futbol wyjaśnia świat czyli nieprawdopodobna teoria globalizacji, thum. A. Czarnecka, Wydawnictwo Red Horse, Lublin.

Fundació FC Barcelona, http://fundacio.fcbarcelona.cat/ Oficjalna strona internetowa Fundacji FC Barcelona (dostęp: 27.11.2015).

Hargreaves, J. 2000. Freedom For Catalonia? Catalan Nationalism, Spanish Identity and the Barcelona Olympic Games, Cambrige University Press, Cambrige.

Hymn FC Barcelony, http://www.fcbarca.com/hymn.html (dostęp: 29.11.2015).

Katalonia - kultura i tradycje katalońskie, http://www.catalunya-polonia.com/page.php?id=66 (dostęp: 27.11.2015).

Kopytoff, I. 2003. Kulturowa biografia rzeczy-utowarowienie jako proces, [w:] Badanie kultury. Elementy teorii antropologicznej, E. Nowicka, M. Kempny (red.), Wydawnictwo Naukowe PWN, Warszawa.

Księżyk, M. 2002. Podstawowe zagadnienia ekonomii, Zakamycze, Kraków.

Kulesza-Gulczyńska, B. 2013. Mecz piłkarski jako rytuat, [w:] Futbol i cała reszta. Sport w perspektywie nauk społecznych, R. Kossakowski, K. Stachura, A. Strzałkowska, M. Żadkowska (red.), Pszczółki.

Leplat, T. 2014. FC Barcelona - Real Madryt. Wojna Światów, thum. W. Wąsowski, Amber, Warszawa.

López Tena, A. 2009. Cataluña bajo España. La opresión national en democracia, Dèria Editors, SL, Barcelona.

Miczyńska-Kowalska, M. 2008. Społeczeństwo konsumenckie jako rys kultury ponowoczesnej w ujęciu Zygmunta Baumana, [w:] Kultura a rynek, S. Patrycki (red.), Wydawnictwo Katolickiego Uniwersytetu Lubelskiego, Lublin.

Miller, G. 2009. Spent: Sex, Evolution, and Consumer Behavior, Viking, New York.

Myśliwiec, M. 2006. Katalonia na drodze do niepodległości?, Wyższa Szkoła Ekonomii i Administracji, Bytom.

Ociepka, B. 2012. Nowa dyplomacja publiczna - perspektywa teorii stosunków międzynarodowych $i$ komunikowania politycznego, „Przegląd Strategiczny”, nr 1.

Relaño, A. 2015. Barça vs. Real. Wrogowie, którzy nie moga bez siebie żyć, tłum. B. Bardadyn, Wydawnictwo SQN, Kraków.

Ritzer, G. 2001. Magiczny świat konsumpcji, Wydawnictwo Literackie MUZA S.A., Warszawa.

Schneider, C. 2004. Culture Communicates: US Diplomacy that Works, „Discussion Papers in Diplomacy”, Clingendael, nr 94.

Serrallonga, U. 2000. El déficit fiscal de Cataluña con España, Òmnium Cultural, Barcelona.

Strubell, M. 1998. Language, Democracy and Devolution in Catalonia. Current Issues in Language and Society, vol. 5, nr 3. 
Szacki, J. 2002. Historia myśli socjologicznej, Wydawnictwo Naukowe PWN, Warszawa.

Szlendak, T. 2004. Supermarketyzacja. Religia i obyczaje seksualne młodzieży w kulturze konsumpcyjnej, Wydawnictwo Uniwersytetu Wrocławskiego, Wrocław.

Wallerstein, I. 2007. Analiza systemów-światów. Wprowadzenie, thum. K. Gawlicz, M. Starnawski, Wydawnictwo Akademickie Dialog, Warszawa.

Wojcieszak, Ł., Głuszek-Szafraniec, D. 2011. Ewolucja ustroju polityczno-terytorialnego Hiszpanii (19752010). Przykład Kraju Basków, Katalonii i Galicji, Wyższa Szkoła Administracji, Bielsko-Biała.

Zeidler-Janiszewska, A. 1998. Formy praktyki artystycznej wobec przemian wspótczesnej kultury, [w:] Kultura polska w nowej sytuacji historycznej, J. Damrosz (red.), Instytut Kultury, Warszawa.

ABSTRACT

Widespread commercialization of almost all aspects of life of the individual is a determinant of changes in the modern world. Comodification and branding are rapidly expanding their area of influence, therefore, they could not omit the area of sport and ethnicity. The creation of FC Barcelona brand is specific, because it is a compilation of global and local features. Catalan identity constitutes, in some measure, an added value to the club, a strong foundation, which also distinguishes Barça premium brand from the rest. At the same time, merchandise that is unique easily finds itself on the economic market and it generates desired profits.

Key words: FC Barcelona, Catalan identity, comodification, branding, football

BIOGRAM

Wioletta Husar, magister politologii i bezpieczeństwa narodowego, absolwentka Uniwersytetu Zielonogórskiego, doktorantka w Zakładzie Teorii i Metodologii Badań Politologicznych Instytutu Politologii Uniwersytetu Zielonogórskiego. Jej zainteresowania badawcze oscylują wokół problematyki mniejszości narodowych i etnicznych, nacjonalizmów peryferyjnych oraz współczesnych przemian politycznych, społecznych i gospodarczych na gruncie hiszpańskim. W rozprawie doktorskiej porusza kwestie ewolucji nacjonalizmu katalońskiego i baskijskiego w warunkach decentralizacji niesymetrycznej. Kontakt e-mail: husar_w@wp.pl. 